\title{
PENGARUH BEBERAPA PUPUK AB MIX TERHADAP TANAMAN HONJE (Etlingera elatior Jack)
}

\section{THE INFLUENCE OF SOME AB MIX FERTILIZERS ON HONJE PLANT (Etlingera elatior Jack)}

\author{
Didit Permadi ${ }^{1}$, Arrin Rosmala ${ }^{2 *}$, Selvy Isnaeni ${ }^{3}$ \\ ${ }^{1}$ Mahasiswa Program Studi Agroteknologi Pertanian, Universitas Perjuangan Tasikmalaya \\ 2,3Dosen Program Studi Agroteknologi Pertanian, Universitas Perjuangan Tasikmalaya
}

Korespondensi: arrinrosmala@unper.ac.id

\begin{abstract}
ABSTRAK
Honje merupakan salah satu tanaman rempah di Indonesia bermanfaat untuk obat-obatan, karena mengandung antioksidan dan anti kanker. Pemupukan menggunakan pupuk AB Mix diharapkan dapatdapat menghasilkan pertumbuhanyang optimal, produksiyang lebih tinggidibandingkan dengan tanaman honje yang ditanam menggunakan pupuk konvensional. Penelitian dilaksanakan pada bulan Maret sampai Juni 2019 di Screen House Rusunawa Universitas Perjuangan, Kota Tasikmalaya. Rancangan percobaan menggunakan rancangan acak lengkap dengan 5 perlakuan dan 5 ulangan. Dosis pupuk yang digunakan yaitu 5 macam jenis pupuk AB Mix dengan dosis1680 ppm. Hasil penelitian menunjukkan pemberian pupuk $\mathrm{AB}$ Mix tidak memberikan pengaruh terhadap semua variabel pengamatan yang meliputi: tinggi tanaman, jumlah daun, panjang dan lebar daun serta jumlah rumpun tanamanhonje.
\end{abstract}

Kata kunci: Honje, Pupuk, Rempah.

\begin{abstract}
Honje is one of the spice plants in Indonesia that used for medicines, because it contains antioxidants and anti-cancer. Fertilization using $\mathrm{AB}$ Mix fertilizer is expected to produce optimal growth, higher production, if compared to honje plants that grown using conventional fertilizer. The study was conducted in March to June 2019 at the Rusunawa Universitas Perjuangan Tasikmalaya screen house, Tasikmalaya City. The experimental design use completely randomized design with 5 treatments and 5 replications. Fertilizer used are 5 types of AB Mix fertilizers with a dosage of 1680 $\mathrm{ppm}$. The results showed that the application of $\mathrm{AB}$ Mix fertilizer had no effect on all observational variables which included: plant height, number of leaves, length and width of leaves as well as the number of clumps of honje plants.

Keywords: Fertilizer, Herbs, Honje.

\section{PENDAHULUAN}

Honje merupakan salah satu tanaman di Indonesia yang sering digunakan sebagai bahan sayuran seperti pecel atau sebagai lalapan, tanaman ini memiliki nama latin (Etlingera elatior Jack). Beberapa tahun terakhir ini honje menjadi perhatian beberapa

peneliti karena memiliki aktivitas anti bakteri dan antioksidan (Syarif et al., 2015). Tanaman honje termasuk family Zingiberaceae dengan tanaman rimpang-rimpangan seperti jahe, kunyit, kencur dan temulawak. Tanaman honje mengandung senyawa aktif seperti tannins, flavonoids, saponin, steroid, dan
\end{abstract}


minyak atsiri (Maimulyanti \& Prihadi, 2015). Hasil penelitian menunjukan tanaman honje mengandung beberapa jenis minyak atsiri yang bersifat bioaktif pada daun, batang, bunga dan rimpang. Menurut penelitian Silvany et al., (2016), batang honje mengandung ekstrak etanol yang bersifat antioksidan kuat bernilai LC 50 44,58 mg.L-1 .

Batang honje digunakan sebagai bahan anyaman dan bahan baku pembuatan kertas (Ibrahim \& Setyowati, 1999). Kuncup sebagai bahan ramuan bumbu kari, dimakan mentah sebagai lalap, disambal atau dimasak dengan sayuran lainnya. Bagian tengah tunas daun sebagai pemberi aroma masakan atau dimakan mentah dengan nasi. Batang direbus dan airnya untuk mandi ibu-ibu selepas melahirkan atau diminum untuk mengobati meriang (Hartini \& Puspitaningtyas, 2005).

Menurut Habsah et al., (2005) tanaman honje dapat dipakai untuk mengobati penyakit-penyakit berat seperti kanker dan tumor. Meningkatnya kesadaran dan kebutuhan masyarakat akan pentingnya mengkonsumsi rempah-rempah serta belum diimbangi dengan produksi honje yang masih rendah karena kurangnya pengetahuan masyarakat terhadap cara pembudidayaan tanaman tersebut. Salah satu cara meningkatkan produksi honje yaitu dengan budidaya menggunakan sistem hidroponik.

Bercocok tanam menggunakan media dapat meningkatkan produksi tanaman dan juga memiliki daya serap air tinggi (Rahmawati, 2018). Pupuk yang digunakan pada penelitian ini yaitu pupuk AB Mix. Terdapat 5 pupuk AB Mix yang digunakan dalam penelitian berdasarkan tempat produksinya, pupuk AB Mix A berasal dari Salatiga, pupuk AB Mix B berasal dari Yogyakarta, pupuk AB Mix C berasal dari Tangerang, pupuk AB Mix D berasal dari Bekasi dan pupuk $\mathrm{AB}$ Mix E berasal dari Surabaya. Pupuk AB Mix memiliki kandungan unsur hara makro dan mikro cukup lengkap yang dibutuhkan untuk pertumbuhan tanaman, sehingga diharapkan pupuk AB Mix dapat mengoptimalkan pertumbuhan tanaman honje. Berdasarkan uraian di atas perlu dilakukan penelitian mengenai "Pengaruh Beberapa Pupuk AB Mix Terhadap Pertumbuhan Tanaman Honje" sehingga dapat diketahui pupuk mana yang dapat menghasilkan tanaman honje berkualitas.

\section{BAHAN DAN METODE}

Penelitian dilaksanakan di Screen House Universitas Perjuangan Tasikmalaya dengan ketinggian tempat 359 mdpl dan curah hujan $302,67 \mathrm{~mm}^{3}$. Penelitian dilaksanakan pada bulan Maret - Juli 2019. Penelitian menggunakan Rancangan Acak Lengkap (RAL) Non Faktorial dengan 5 perlakuan dan 5 ulangan sehingga terdapat total 25 tanaman. Adapun rinciannya sebagai berikut: Perlakuan A: Pupuk AB Mix A 1680 ppm Perlakuan B: Pupuk AB Mix B 1680 ppm Perlakuan C: Pupuk AB Mix C 1680 ppm Perlakuan D: Pupuk AB Mix D 1680 ppm Perlakuan E: Pupuk AB Mix E 1680 ppm Pemberian perlakuan dosis 1680 ppm dengan cara mencampurkan larutan pupuk AB Mix ke dalam air dengan takaran 1,075 ml sampai dicapai total larutan pupuk sebanyak $1.750 \mathrm{ml}$ per 5 polybag, setelah itu larutan di ukur menggunakan TDS meter. 
HASIL DAN PEMBAHASAN

Tabel 1. Hasil analisis kandungan pupuk

\begin{tabular}{cccc}
\hline \multirow{2}{*}{ Perlakuan } & \multicolumn{3}{c}{ Parameter } \\
\cline { 2 - 4 } & N (\%) & P205 (\%) & K20 (\%) \\
\hline A & 0,07 & 1,24 & 0,07 \\
B & 0,16 & 0,48 & 0,12 \\
C & 0,05 & 0,27 & 0,19 \\
D & 0,05 & 1,40 & 0,08 \\
E & 0,04 & 0,01 & 0,14 \\
\hline
\end{tabular}

Hasil analisis kandungan unsur N, P, K pada perlakuan pupuk AB Mix yang dilakukan di Laboratorium Kimia Tanah dan Nutrisi Tanaman Universitas Padjadjaran, tertuang pada Tabel 1. Hasil menunjukan bahwa kandungan unsur $\mathrm{N}$ paling tinggi terdapat pada pupukAB Mix B. Kandungan unsur Pyang paling tinggi terdapat pada pupuk AB Mix D, dan kandungan unsur K paling tinggi terdapat pada pupuk $\mathrm{AB}$ Mix C.

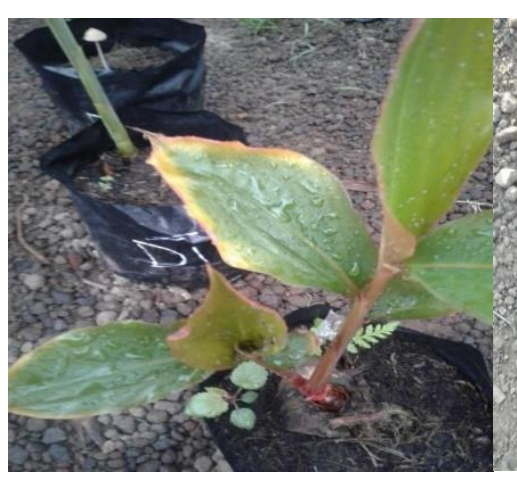

(a)

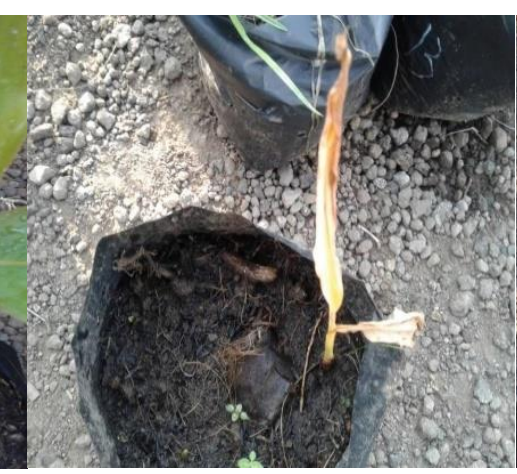

(b)

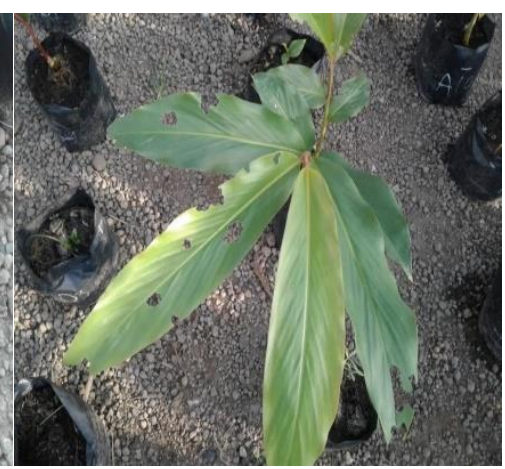

(c)

Gambar 1. (a). Hama; (b). Penyakit; (3). Gulma yang menyerang tanaman honje.

Hama yang menyerang pada penelitian tanaman honje yaitu ulat kantung (Mahasena corbetti tams). Hama tersebut menyerang daun tanaman honje sehingga daun menjadi berlubang sehingga proses fotosintesis menjadi terganggu. Pengendalian yang dilakukan dengan cara manual, mengambil hama dari daun tanam dan membunuhnya, pengendalian secara fisik dilakukan dengan cara mengatur faktor-faktor fisik yang dapat mempengaruhi perkembangan ulat kantung sehingga tercipta kondisi yang tidak ideal bagi perkembangbiakannya. Penyakit yang menyerang pada tanaman honje selama penelitian yaitu penyakit layu bakteri (Ralstonia solanacearum). Gejala yang ditimbulkan yaitu seluruh bagian daun menjadi kuning, layu, kering, yang menyebabkan tanaman menjadi mati. Gulma yang menyerang yaitu gulma kersen (Muntingia calabura L.), paku-pakuan (Pteridophyta),dan rumput. Pengendalian yang dilakukan dengan carateknikmanualdengan mencabut langsung dari sekitar polybag.

Data pada Tabel 2 menunjukan bahwa semua perlakuan pupuk $\mathrm{AB}$ Mix tidak memberikan perbedaan pengaruh yang nyata terhadap tinggi tanaman honje pada semua umur pengamatan. Perlakuan pemberian pupuk AB Mix tidak memberikan hasil yang berbeda nyata pada tinggi tanaman dikarenakan belum optimumnya dosis yang diberikan. Akan tetapi, pengamatan yang dilakukan selama 12 minggu terhadap tinggi tanaman honje memperlihatkan bahwa laju 
pertumbuhan tinggi tanaman yang diberi perlakuan pupuk AB Mix A menghasilkan laju pertumbuhan tinggi tanaman paling tinggi dibandingkan dengan perlakuan lainnya. Diduga karena kandungan dosis pada pupuk AB Mix A lebih tepat untuk pertumbuhan tanaman honje tersebut. Menurut Wang et al. (2007) dan Homer (2008) bahwa kondisi pertumbuhan tanaman yang baik disebabkan tercukupinya unsur hara $\mathrm{N}$ yang akan menyebabkan tanaman mampu menyerap unsur P secara efektif.

Tabel 2. Pengaruh Pupuk AB Mix Terhadap Tinggi Tanaman Honje

\begin{tabular}{cccccc}
\hline \multirow{2}{*}{ Perlakuan } & \multicolumn{5}{c}{ Tinggi tanaman (cm) } \\
\cline { 2 - 6 } & $\mathbf{4} \mathbf{~ m s t}$ & $\mathbf{6} \mathbf{~ m s t}$ & $\mathbf{8} \mathbf{~ m s t}$ & $\mathbf{1 0} \mathbf{~ m s t}$ & $\mathbf{1 2} \mathbf{~ m s t}$ \\
\hline A & $26,8 \mathrm{a}$ & $36,8 \mathrm{a}$ & $43,1 \mathrm{a}$ & $50,7 \mathrm{a}$ & $55,6 \mathrm{a}$ \\
$\mathrm{B}$ & $21,9 \mathrm{a}$ & $29,0 \mathrm{a}$ & $32,7 \mathrm{a}$ & $39,3 \mathrm{a}$ & $46,8 \mathrm{a}$ \\
C & $14,9 \mathrm{a}$ & $19,5 \mathrm{a}$ & $23,9 \mathrm{a}$ & $28,6 \mathrm{a}$ & $35,3 \mathrm{a}$ \\
D & $20,9 \mathrm{a}$ & $23,8 \mathrm{a}$ & $29,3 \mathrm{a}$ & $34,4 \mathrm{a}$ & $38,5 \mathrm{a}$ \\
E & $23,0 \mathrm{a}$ & $28,3 \mathrm{a}$ & $30,3 \mathrm{a}$ & $37,2 \mathrm{a}$ & $40,5 \mathrm{a}$ \\
\hline
\end{tabular}

Keterangan: nilai rata-rata yang ditandai huruf yang sama pada kolom yang sama menunjukan tidak berbeda nyata menurut LSD padataraf $5 \%$.

Tabel 3. Pengaruh Pupuk AB Mix Jumlah Daun Tanaman Honje (helai)

\begin{tabular}{cccccc}
\hline \multirow{2}{*}{ Perlakuan } & \multicolumn{5}{c}{ Jumlah Daun (helai) } \\
\cline { 2 - 5 } & $\mathbf{4} \mathbf{~ m s t}$ & $\mathbf{6} \mathbf{~ m s t}$ & $\mathbf{8} \mathbf{~ m s t}$ & $\mathbf{1 0} \mathbf{~ m s t}$ & $\mathbf{1 2} \mathbf{~ m s t}$ \\
\hline A & $3,2 \mathrm{a}$ & $5,0 \mathrm{a}$ & $6,8 \mathrm{a}$ & $9,2 \mathrm{a}$ & $11,2 \mathrm{a}$ \\
B & $2,8 \mathrm{a}$ & $4,0 \mathrm{a}$ & $5,2 \mathrm{a}$ & $6,6 \mathrm{a}$ & $8,2 \mathrm{a}$ \\
C & $2,2 \mathrm{a}$ & $3,8 \mathrm{a}$ & $4,6 \mathrm{a}$ & $6,2 \mathrm{a}$ & $7,4 \mathrm{a}$ \\
D & $1,8 \mathrm{a}$ & $2,6 \mathrm{a}$ & $4,6 \mathrm{a}$ & $6,4 \mathrm{a}$ & $7,8 \mathrm{a}$ \\
E & $2,4 \mathrm{a}$ & $4,0 \mathrm{a}$ & $5,4 \mathrm{a}$ & $6,6 \mathrm{a}$ & $8,2 \mathrm{a}$ \\
\hline
\end{tabular}

Keterangan: nilai rata-rata yang ditandai huruf yang sama pada kolom yang sama menunjukan tidak berbeda nyata menurut LSD padataraf5\%.

Berdasarkan Tabel 3 menunjukan bahwa semua perlakuan pupuk AB Mix tidak memberikan perbedaan pengaruh yang nyata terhadap jumlah daun honje pada semua umur pengamatan. Perlakuan pemberian pupuk $\mathrm{AB}$ Mix tidak berpengaruh nyata terhadap jumlah daun tanaman honje. Akan tetapi dilihat pada Tabel 3, pupuk AB Mix A cenderung menghasilkan jumlah daun yang lebih banyak dibandingkan dengan pupuk $A B$ Mix yang lain. Unsur N mempunyai peranan penting dalam pembentukan klorofil, protoplasma, protein dan asam nukleat dalam pertumbuhan dan perkembangan tanaman seperti pada tinggi tanaman, jumlah daun, panjang daun, lebar daun dan jumlah rumpun (Brady \& Weil, 2002).

Tabel 4. Pengaruh Pupuk AB Mix Panjang Daun Tanaman Honje (cm)

\begin{tabular}{cccccc}
\hline \multirow{2}{*}{ Perlakuan } & \multicolumn{5}{c}{ Panjang Daun (cm) } \\
\cline { 2 - 6 } & $\mathbf{4} \mathbf{~ m s t}$ & $\mathbf{6 ~ \mathbf { ~ m s t }}$ & $\mathbf{8} \mathbf{~ m s t}$ & $\mathbf{1 0} \mathbf{~ m s t}$ & $\mathbf{1 2} \mathbf{~ m s t}$ \\
\hline $\mathrm{A}$ & $19,9 \mathrm{a}$ & $23,0 \mathrm{a}$ & $24,9 \mathrm{a}$ & $25,4 \mathrm{a}$ & $25,8 \mathrm{a}$ \\
$\mathrm{B}$ & $16,0 \mathrm{a}$ & $18,9 \mathrm{a}$ & $20,7 \mathrm{a}$ & $21,0 \mathrm{a}$ & $21,9 \mathrm{a}$ \\
C & $10,4 \mathrm{a}$ & $13,9 \mathrm{a}$ & $16,0 \mathrm{a}$ & $17,8 \mathrm{a}$ & $18,7 \mathrm{a}$ \\
D & $11,6 \mathrm{a}$ & $13,8 \mathrm{a}$ & $16,7 \mathrm{a}$ & $18,1 \mathrm{a}$ & $18,3 \mathrm{a}$ \\
E & $13,5 \mathrm{a}$ & $15,7 \mathrm{a}$ & $17,2 \mathrm{a}$ & $17,8 \mathrm{a}$ & $18,5 \mathrm{a}$ \\
\hline
\end{tabular}

Keterangan: nilai rata-rata yang ditandai huruf yang sama pada kolom yang sama menunjukan tidak berbeda nyata menurutLSD padataraf $5 \%$. 
Tabel 5. Pengaruh Pupuk AB Mix Lebar Daun Tanaman Honje (cm)

\begin{tabular}{cccccc}
\hline \multirow{2}{*}{ Perlakuan } & \multicolumn{5}{c}{ Lebar Daun (cm) } \\
\cline { 2 - 6 } & $\mathbf{4} \mathbf{~ m s t}$ & $\mathbf{6} \mathbf{~ m s t}$ & $\mathbf{8} \mathbf{~ m s t}$ & $\mathbf{1 0} \mathbf{~ m s t}$ & $\mathbf{1 2} \mathbf{~ m s t}$ \\
\hline A & $5,5 \mathrm{a}$ & $5,8 \mathrm{a}$ & $6,3 \mathrm{a}$ & $6,3 \mathrm{a}$ & $6,3 \mathrm{a}$ \\
B & $5,2 \mathrm{a}$ & $5,3 \mathrm{a}$ & $5,5 \mathrm{a}$ & $5,5 \mathrm{a}$ & $5,7 \mathrm{a}$ \\
C & $4,2 \mathrm{a}$ & $4,6 \mathrm{a}$ & $4,7 \mathrm{a}$ & $5,2 \mathrm{a}$ & $5,2 \mathrm{a}$ \\
D & $3,3 \mathrm{a}$ & $3,5 \mathrm{a}$ & $4,7 \mathrm{a}$ & $4,7 \mathrm{a}$ & $4,7 \mathrm{a}$ \\
E & $4,2 \mathrm{a}$ & $4,5 \mathrm{a}$ & $4,7 \mathrm{a}$ & $5,0 \mathrm{a}$ & $5,1 \mathrm{a}$ \\
\hline
\end{tabular}

Keterangan: nilai rata-rata yang ditandai huruf yang sama pada kolom yang sama menunjukan tidak berbeda nyata menurut LSD padataraf $5 \%$.

Hasil penelitian dengan memberikan perlakuan pupuk AB Mix tidak berpengaruh nyata terhadap panjang dan lebar daun tanaman honje. Akan tetapi, Tabel 4 dan Tabel 5 menunjukkan bahwa pemberian pupuk $\mathrm{AB}$ Mix A cenderung menghasilkan tanaman honje dengan panjang daun paling panjang dan lebar daun paling lebar dibandingkan dengan perlakuan pupuk AB Mix lainnya. Unsur N merupakan unsur yang paling banyak dibutuhkan tanaman setelah $\mathrm{C}, \mathrm{H}, \mathrm{O}$ diserap dalam bentuk nitrat dan ammonium untuk fase vegetatif. Unsur $\mathrm{N}$ mudah menguap Tabel 6. Pengaruh Pupuk AB Mix Jumlah Anakan Tanaman Honje

\begin{tabular}{cccccc}
\hline \multirow{2}{*}{ Perlakuan } & \multicolumn{5}{c}{ Jumlah Anakan } \\
\cline { 2 - 6 } & $\mathbf{4} \mathbf{~ m s t}$ & $\mathbf{6} \mathbf{~ m s t}$ & $\mathbf{8} \mathbf{~ m s t}$ & $\mathbf{1 0} \mathbf{~ m s t}$ & $\mathbf{1 2} \mathbf{~ m s t}$ \\
\hline A & $1,2 \mathrm{a}$ & $2,0 \mathrm{a}$ & $1,8 \mathrm{a}$ & $2,2 \mathrm{a}$ & $2,0 \mathrm{a}$ \\
B & $1,0 \mathrm{a}$ & $1,0 \mathrm{a}$ & $1,2 \mathrm{a}$ & $1,4 \mathrm{a}$ & $1,6 \mathrm{a}$ \\
C & $1,0 \mathrm{a}$ & $1,0 \mathrm{a}$ & $1,2 \mathrm{a}$ & $1,6 \mathrm{a}$ & $1,2 \mathrm{a}$ \\
D & $1,0 \mathrm{a}$ & $1,0 \mathrm{a}$ & $1,6 \mathrm{a}$ & $1,6 \mathrm{a}$ & $1,8 \mathrm{a}$ \\
E & $1,2 \mathrm{a}$ & $1,2 \mathrm{a}$ & $1,4 \mathrm{a}$ & $1,4 \mathrm{a}$ & $1,8 \mathrm{a}$ \\
\hline
\end{tabular}

Keterangan: nilai rata-rata yang ditandai huruf yang sama pada kolom yang sama menunjukan tidak berbeda nyata menurut LSD padataraf $5 \%$.

Hasil analisis ragam mengenai pengaruh pupuk $\mathrm{AB}$ Mix terhadap jumlah anakan honje menunjukan bahwa semua perlakuan pupuk AB Mix tidak memberikan perbedaan pengaruh yang nyata terhadap jumlah anakan honje pada semua umur pengamatan. Januwati (1999) dalam Fithryan (2009) yang menyatakan bahwa kontribusi pupuk NPK menyediakan unsur hara esensil yang mempunyai fungsi dan peran tersendiri sehingga tanaman seringkali mengalami defisiensi. Kandungan nutrisi $\mathrm{P}$ mempunyai peranan penting dalam meningkatkan pertumbuhan tanaman, penyusunan senyawa untuk pemberian energi nucleoprotein, sistem informasi genetik (DNA dan RNA), membran sel dan fosfoprotein jika tercukupi dapat meningkatkan pertumbuhan akar. Unsur $\mathrm{K}$ memiliki kebutuhan sama dengan unsur $\mathrm{N}$ yang mempunyai aktivitas enzim, turgor tanaman, fotosintesis dan pembentukan karbohidrat. (Havlin et al., 2005).

akan mempengaruhi kualitas tanaman. Peranan nitrogen adalah perangsang pertumbuahan vegetatif, yaitu menambah tinggi tanaman, merangsang tumbuhnya anakan dan membuat tanaman menjadi hijau karena merupakan bahan penyusun klorofil yang penting dalam fotosintesis. Akan tetapi penggunaan pupuk yang berlebihan atau kekurangan tidak berpengaruh terhadap tanaman. Berdasarkan pada Tabel 6 diketahui bahwa perlakuan pemberian pupuk AB Mix tidak berpengaruh 
nyata, diduga kandungan unsur N, P, K pada pupukAB Mixkurang. Akan tetapi dilihat pada Tabel 6 bahwa pemberian pupuk AB Mix A lebih banyak jumlah anakan dibandingkan dengan pemberian pupuk AB Mix yang lain.

\section{SIMPULAN}

Pemberian pupuk AB Mix dengan dosis 1680 ppm dalam penelitian ini tidak berpengaruh terhadap semua variabel pertumbuhan yang diamati, meliputi : tinggi tanaman, jumlah daun, panjang dan lebar daun sertajumlahrumpuntanamanhonje.

\section{DAFTAR PUSTAKA}

Brady, N.C \& Weil, R.R. (2002). The nature and properties of soils. 13* Edition., New Jersey. USA: Upper Saddle River.

Fithryan, D.S. (2009). Respons pertumbuhan dan produksi jahe (Zingiber officinale Rosc.) Sistem keranjang terhadap jumlah bibit dan pemberian pupuk majemuk NPK. Skripsi. Universitas Sumatera Utara.Medan.

Habsah, M., Lajis, N.H., Sukari. M.A., Yap, Y.H., Kikuzaki, H., Nakatani, N., \& Ali, A.M. (2005). Antitumour-promoting and cytotoxic constituents of Etlingera elatior. Malaysian journal of Medical Sciences. 12:6-12

Hartini,S \& Puspitaningtyas, D.M. (2005). Flora Sumatera Utara eksotik dan berpotensi. Bogor (ID): Pusat Konservasi Tumbuhan Kebun Raya Bogor LIPI.

Haraguchi, H., Yuwata K, Inada K, Shingu K, Miyahara K, Nagao M, \& Yagi A. (1998). Antifungal activity from a. galanga and the competition for incorporation of unsarturated fatty acid in cell growth.Plant Medicine.62 (4) : 308-313

Havlin JL, Beaton JD, Tisdale SL, \& Nelson WL. (2005). Soil fertility and fertilizers. An intoduction to nutrient management. Seventh Edition. New Jersey : Pearson Education Inc. Upper Saddle River.

Homer ER. (2008). The effectnitrogen application timming on plant available phosphorus. Thesis. Graduate school of The Ohio State University. USA.

Maimulyanti A., \& Prihadi A.R. (2015). Chemical composition, phytochemical and antioxidant activity from extract of Etlingera elatior flower from Indonesia. Journal of Pharmacognosy and Phytochemistry, 3(6), 233-238.

Ibrahim H \& Setyowati FM. (1999). Etlingera Giseke dalam: de Guzman CC, Siemonsma JS, editors. Plant Resources of South-East Asia 13 : Spices. Leiden: Backhuys Publisher.

Silvany R., Ginting M., \& Ginting A. (2016). Pengujian antioksidan minyak atsiri, ekstrak air, dan ekstrak etanol dari batang kecombrang (Etlingera elatior) dengan metode DPPH. Chempublish Journal, 1(2), 1-6.

Januwati M. (1999). Optimalisasi usaha tani tanaman jahe. Makalah disampaikan pada semi orasi di Balai Penelitian tanaman rempah dan obat Bogor, 23 Juni $1999.31 \mathrm{hlm}$.

Rahmawati E. (2018). Pengaruh berbagai jenis media tanam dan konsentrasi nutrisi larutan hidroponik terhadap pertumbuhan tanaman mentimun Jepang (Cucumis sativas). Skripsi. Fakultas Sains dan Teknologi UIN Alauddun. Makassar.

Syarif R.A., Sari F., \& Ahmad A.R. (2015). Rimpang kecombrang (Etlingera elatior Jack) sebagai sumber fenolik. Jurnal Fitofarmaka Indonesia, Vol 2 (2), 102-106.

Wang YP, Houlton BZ, \& Field CB. (2007). A model of biogeochemical cycles of carbon, nitrogen, and phosphorus including symbiotic nitrogen fixation and phosphatase production. Global Biogeochemical Cycles 21, 1018-1029. 